\title{
Evaluation of Drug-Related Problems in Ischemic Stroke Patients Undergoing Inpatients at the National Brain Center Hospital (RSPON) in 2018
}

\author{
Tati Suprapti ${ }^{1 *}$, Gloria Murtini² and Masfiah $^{3}$ \\ 1,2 Department of Pharmacy, Polytechnic of Health, Ministry of Health Republic of Indonesia Jakarta II \\ Jakarta, Indonesia. \\ ${ }^{3}$ National Brain Center Hospital (RS PON) \\ Jakarta, Indonesia \\ *Corresponding author's email: tatisuprapti55 [AT] gmail.com
}

\begin{abstract}
Stroke is a cerebrovascular disease that is increasingly found. Stroke carries a high risk of death. Victims can reverse vision and /or talk, paralysis, and confusion. ${ }^{1}$ In Indonesia, around 550,000 new stroke patients every year. This figure is considered to be very high and ranks third as the cause of death in Indonesia, after cardiovascular and cancer. ${ }^{2}$ Many factors can cause stroke, diabetes, hypertension, and high cholesterol levels, so treatment is needed for more complicated drug therapy to deal with stroke and its associated diseases. ${ }^{3}$ The more complex the drug, the more challenging the doctor to receive the right drug therapy. Therefore, in clinical practice, various drug-related problems can increase. ${ }^{4,5}$ Therefore, identifying DRP is an important priority for health professionals to improve health-related quality of life in stroke patients. ${ }^{6,7}$
\end{abstract}

OBJECTIVE_Evaluating drug-related problems in ischemic stroke patients undergoing hospitalization at the National Brain Center Hospital (PON) in 2018

METHOD_Non-experimental research with quantitative descriptive analysis using medical records of inpatient ischemic stroke patients.

RESULTS AND CONCLUSIONS_174 male ischemic stroke patients (69.32\%); 77 female patients (30.68\%); The age of most ischemic stroke patients was in the range of $50-59$ years 85 patients (33.86\%); and the least was at the age of <40 years; 7 people (2.79\%); Most types of JKN insurance financing were used by 220 people (87.64\%) at least 1 patient was guaranteed by the company (0.40\%); The longest stay in the hospital was 60 days for a maximum of 1 person $(0.40 \%)$ and the shortest was 3-10 days for 225 people (89.64\%); The most prescribed number of drug items was $70-80$ items per person $(0,40 \%)$ and the least was 5 to 10 drug items received by 60 patients $(23,90 \%)$; Most comorbidities were hypertension + dyslipidemia 83 patients (33.03\%) and the least was hypertension 5 people (1.98\%); The most prescribed group of drugs was 468 prescribing (13.81\%) drugs which affecting the blood clotting process, and the least prescription antibiotic medications was 122 times (3.63\%); Medication errors, were the most given drugs, with a very large dose of 13 times (43.33\%) and the least wrong drug; wrong dose; wrong dosage form; and the wrong frequency for each was 1 case (3.3\%); Drug interactions which had the most moderate criteria were 1313 cases.

Keywords - Ischemic Stroke, PON Hospital, Drug- related Problems

\section{INTRODUCTION}

Stroke is a cerebrovascular disease that is increasingly found. Stroke carries a high risk of death. Victims can reverse vision and /or talk, paralysis, and confusion. Causing factors of stroke are high Sodium diet, smoking, and diseases that trigger it, such as cardiovascular disease, hypertension, diabetes, and high level of lipids in the blood. ${ }^{1}$ Stroke according to World Health Organization is clinical signs that develop quickly as the result of local (or global) cerebral function disorder within 24-hour or more, and can cause death without other causes except for vascular disruption. ${ }^{1}$

Stroke contributes to a number of deaths as the highest cause in South East of the U.S. Stroke kills approximately 140.000 people in U.S, every year with a ratio of 1:20 deaths. In every 40 seconds' stroke strikes one person, and in every four minutes, one person dies because of stroke. Every year, more than 795.000 people in the U.S got a stroke, with 610.000 among them have experienced a stroke for the first time, while the rest have experienced stroke more than once. Around $87 \%$ of stroke cases are ischemic stroke, which caused by bloodstreams to the brain that clogged up. 
Annually in the U.S, stroke requires around \$34 Billion include healthcare costs drug cost and lost working days. As the main cause of serious long term disability, stroke can also lower mobilization in more than half of stroke patients older than 65 years old. ${ }^{2}$

In Indonesia, there are 550.000 new stroke patients every year. This can be concluded as a high amount and considered as the third of death causes in Indonesia, after cardiovascular and cancer, respectively. About $15.4 \%$ of deaths in almost all hospitals in Indonesia caused by stroke. Basic Health Research / Riset Kesehatan Dasar (RISKESDAS) Ministry of Health of Republic Indonesia in 2013 showed that there was an increasing prevalence of stroke in Indonesia from 8.3 per mil in 2007 to 12.1 per mil in 2013. The highest prevalence was in North Sulawesi (10.8 per mil), Yogyakarta (10.3 per mil), Bangka Belitung (9.7 per mil) and DKI Jakarta (9.7 per mil). Stroke prevalence tends to be higher in lower educational grade communities and other communities living in the city. People with stroke are predicted to increase 25-30 per mil in the future. Furthermore, half of the patient will end up with a disability, with the level of disability up to $65 \%$ according to some studies. ${ }^{3}$

There are a lot of risk factors that cause stroke, among them are cardiovascular disease, diabetes, hypertension, and high cholesterol level. Furthermore, for the treatment, it will need complex drug therapy for coping with the stroke and comorbidities. ${ }^{4}$ The more complex the drug therapy, the bigger challenge to the doctor for making proper prescription. Therefore, in clinical practice, various problems including drug-related problem (DRP) can increase. DRP usually occurs to the patient that treated in hospital, and could increase morbidities and mortalities in the patient along with the cost. ${ }^{5,6}$ Identifying, preventing, and solving DRP are major issues in the pharmaceutical care process. DRP, defined as a real occurrence or condition or potentially disrupts desired health status, which can cause pharmacotherapy ineffective, also morbidities and mortality that related to the drug. ${ }^{7}$

A pharmacist has an important role to identify DRP, solve actual DRP, and prevent potential DRP in pharmaceutical care. ${ }^{5}$ Actual DRP is defined as a proven condition in patients, while potential DRP is defined as an unproven condition but probably proven in patients if the pharmacist doesn't give proper intervention. ${ }^{8}$ Some studies reveal that patient with stroke has a higher risk to get DRP because of polypharmacy, elderly, and comorbidities. Therefore, identifying DRP is an important priority for health practitioners to promote quality of life which related to the health status of the patients. ${ }^{8,9}$

Therefore, studies of Drug-Related Problem in stroke patients which in inpatients care, which could give hints about DRP occurrence, so that it could be prevented and the excessive cost could be avoided by hospital and patients themselves. From all stroke patients at PON Hospital in 2018, two-thirds had an ischemic stroke, while the rest were hemorrhagic stroke. It's called an ischemic stroke because of blockage in the blood vessels by thromboembolic which makes the area under got ischemic. The amount of ischemic stroke patients and the various drugs given to them, gave the authors an opportunity to conduct a study about "Evaluation of Drug-Related Problems in Ischemic Stroke Patients Undergoing Inpatients at the National Brain Center (PON) Hospital in 2018".

\subsection{Statement of the Problem}

Statement of the problem was about the issues related to the drug (Drug-Related Problem) at inpatients stroke patients in PON Hospital Jakarta in 2018.

\subsection{General Objectives}

\section{OBJECTIVES OF THE STUDY}

This study is conducted generally for describing Drug-Related Problem at inpatients stroke patients in PON Hospital Jakarta in 2018.

\subsection{Specific Objectives}

This study is conducted specifically for describing:

\subsubsection{Stroke Patients Demographic Data:}

1. Gender distribution

2. Age distribution

3. Types of Patient Care Financing

4. Duration of inpatient

5. Various and amount of drug

6. Comorbidities

7. Top ten most prescribed drugs

3.2.2 Various Problem Related to Drugs:

8. Medication Error

a. Wrong Patients

b. Wrong Drugs

c. Wrong Drugs Dosage

d. Wrong Form of Drugs

e. Wrong Directions of Drug Use

f. Prescription Duplicate 
g. Wrong Directions of Drug Use

h. Prescription Duplicate

i. Receiving Drug Unsuccessfully

j. Too-small Dosage

k. Too-much Dosage

1. Unwanted Drug Reaction

9. Drug Interactions

\section{SIGNIFICANCE OF THE STUDY}

4.1 For the author: to gain clinic experience and information related to the drug on stroke patients.

4.2 For PON Hospital: to give information which can be considered in composing therapy guide for inpatient stroke patients at Intensive Care PON Hospital.

4.3 For pharmacy department of Poltekkes Kemenkes Jakarta II: to improve the accreditation score by publishing the study in an international journal.

\section{STUDY DESIGN}

This is a non-experimental study with descriptive quantitative analysis using the medical record of inpatient stroke patients at Pharmacy Installation PON Hospital which collected retrospectively during 2018.

\section{PLACE AND TIME}

This study was conducted in Inpatients Installation at PON Hospital in August-October 2019.

\section{SAMPLE AND POPULATION}

The sample and population of this study were taken from the medical record of all inpatient ischemic stroke patients within January until December 2018. Patients which included in inclusion criteria were inpatients stroke patients at PON Hospital with complete medical record and laboratory check-up, while the exclusion criteria were inpatients stroke patients at PON Hospital with incomplete, unreadable or missing medical record and laboratory check-up, ICU patients, HCU patients, fatality, transferred to another hospital, and forcibly discharged patients. Instruments used in this study were a form that included the patient's medical record number, age, gender, education, occupation, which drugs were being used and the composition of the dosage. Acquired data was analyzed descriptively which included patient's characteristics and usage of stroke drugs in inpatients stroke patients at PON Hospital.

The number of samples which included in inclusion and exclusion criteria in 2018 is 673 patients. Slovin method was employed and the number of samples used for this study, as follows:

The calculation is:

$\mathrm{n}$ = amount of sample being used

$\mathrm{N}=$ amount of all patients

e $=$ margin of error $(5 \%)$

$\mathrm{n}=673 /\left(1+\left(673 \times 0,05^{2}\right)\right.$

$\mathrm{n}=673 /(1+1,6825)=250,88$ rounded to 251

Amount of sample being used is 251

\section{DATA COLLECTION}

The data resource was taken from the primary data of inpatients stroke patients' medical records within 2018.

\section{METHODOLOGY}

Preparation for the study (looking up to related journals, books, and Ethical Committee Permission) and Research Cooperate Decree between PON Hospital's Director and Poltekkes Kemenkes Jakarta II's Director. After obtaining two required documents mentioned before, the authors submitted a Data Collection Permission letter to PON Hospital's Director.

\section{DATA COLLECTION PROCEDURE}

Data procession technique was done by collecting the medical record data of inpatient stroke patients at Pharmacy Installation PON Hospital within 2018.

The data was analyzed in the following procedures:

\section{DATA ANALYSIS}

11.1 Compiling name, gender, and age of stroke patients, and the duration of inpatients.

11.2 Compiling the name of drugs and regimens of drug delivery.

11.3 Compiling drug therapy classes.

11.4 Analyzing the data by counting the number and each percentage.

15.5 Presenting the data in the form of a table. 


\section{PROCEDURES TO KEEP PATIENTS AND HOSPITAL CONFIDENTIALITY}

To keep their confidentiality, their name and medical record number were written in an initial code, the same as the name of the hospital.

\section{RELATIVE RISK ESTIMATION TO STUDY SUBJECT AND/OR PON HOSPITAL}

If the patients' name and PON Hospital did not use initial, and the patients viewed their data stated incorrectly in the study, it would be a disadvantage for them and the hospital, and could be an issue in the future. Therefore, the authors must keep the patients' identity, medical record, and the hospital's identity confidential by using an initial.

\section{STUDY ETHICS}

This study was approved by The Ethical Committee Research Department PON Hospital based on the Approval Letter Number: UM.01.05/12/044/2019.

\section{RESULTS}

The study of Drug-Related Problem in inpatients ischemic stroke at PON Hospital within 2018 was conducted with 251 patients as a sample, and the results are as follows :

Table 1. Gender Distribution of Ischemic Stroke Patients within 2018

\begin{tabular}{lcc}
\hline Gender & Number of patients & Percentage $(\%)$ \\
\hline Male & 174 & 69,32 \\
Female & 77 & 30,68 \\
\hline Total & 251 & 100,00 \\
\hline
\end{tabular}

As shown in Table 1, from 251 samples, the number of male patients is more than female patients, 174 people $(69,32 \%)$ and 77 people $(30,68 \%)$ respectively.

Table 2. Age Distribution of Ischemic Stroke Patients within 2018

\begin{tabular}{llcc}
\hline No. & Age & Number of patients & Percentage $(\%)$ \\
\hline 1. & $<40$ & 7 & 2,79 \\
2. & $40-49$ & 36 & 14,34 \\
3. & $50-59$ & 85 & 33,86 \\
4. & $60-69$ & 77 & 30,68 \\
5. & $70-79$ & 33 & 13,15 \\
6. & $80-89$ & 13 & 5,18 \\
\hline & Total & 251 & 100,00 \\
\hline
\end{tabular}

As shown in Table 2, the highest number of ischemic patients at the age of 50-59 years old is $30,86 \%$, while the lowest number at the age of $<40$ years old is $2,79 \%$.

Table 3. Types of Patient Care Financing (Insurance) of Ischemic Stroke Patients within 2018

\begin{tabular}{clcc}
\hline No. & \multicolumn{1}{c}{ Insurance Type } & Number of Patients & Percentage (\%) \\
\hline 1. & Private Insurance (Asuransi Swasta) & 2 & 0,80 \\
2. & Government Insurance (JKN*) & 220 & 87,64 \\
3. & Company (Perusahaan) & 1 & 0,40 \\
4. & General (Umum) & 28 & 11,16 \\
\hline \multicolumn{2}{c}{ Total } & 251 & 100,00 \\
\hline JKN $=$ Jaminan Kesehatan Nasional
\end{tabular}

As shown in Table 3. the highest number of ischemic patients using Government Insurance (JKN) is 220 people $(87,64) \%$, while the lowest number using Company financial insurance is 1 person $(0,80 \%)$. 
Table 4. Length of Stay of Ischemic Stroke Patients within 2018

\begin{tabular}{cccc}
\hline No. & Length of Stay (Days) & Number of Patients & Percentage $(\%)$ \\
\hline 1. & $3-10$ & 225 & 89,64 \\
2. & $10-20$ & 19 & 7,56 \\
3. & $20-30$ & 3 & 1,20 \\
4. & $30-40$ & 1 & 0,40 \\
5. & $40-50$ & 1 & 0,40 \\
6. & $50-60$ & 1 & 0,40 \\
7. & $>60$ & 1 & 0,40 \\
\hline & Total & 251 & 100,00 \\
\hline
\end{tabular}

As shown in Table 4. the longest length of stay from 3 up to 10 days is 225 patients $(89,64 \%)$, while the shortest is between 30-40, 40-50, 50-60, and more than 60 days with one patient only $(0,40 \%)$ for each group.

Table 5. Number of Prescribed Drugs to Ischemic Stroke Patients within 2018

\begin{tabular}{cccc}
\hline No. & Number of Prescribed Drugs & Number of Patients & Percentagen $(\%)$ \\
\hline 1. & $5-10$ & 60 & 23,90 \\
2. & $10-20$ & 143 & 56,97 \\
3. & $20-30$ & 34 & 13,54 \\
4. & $30-40$ & 9 & 3,59 \\
5. & $40-50$ & 1 & 0,40 \\
6. & $50-60$ & 2 & 0,80 \\
7. & $60-70$ & 1 & 0,40 \\
8. & $70-80$ & 1 & 0,40 \\
\hline & Total & 251 & 100,00 \\
\hline
\end{tabular}

As shown in Table 5. the patients mostly received 10-20 items of drugs were 143 patients $(13,54 \%)$. On the other hand, respectively one patient received 40-50, 60-70, and 70-80 items.

Table 6. Number of Prescribed Drugs to Ischemic Stroke Patients within 2018

\begin{tabular}{llcc}
\hline No. & \multicolumn{1}{c}{ Primary Comorbidities } & Number of Patients & Percentage (\%) \\
\hline 1. & Hypertension + Hyperlipidemia & 83 & 33,03 \\
2. & Hypertension + Hyperlipidemia + Type 2 DM & 69 & 27,48 \\
3. & Hyperlipidemia + Type 2 DM & 49 & 19,52 \\
4. & Hyperlipidemia & 36 & 14,41 \\
5. & Hypertension + Type 2 DM & 9 & 3,56 \\
6. & Hypertension & 5 & 1,98 \\
\hline & & 251 & 100,00 \\
\hline
\end{tabular}

As shown in Table 6, the patients mostly have hypertension and hyperlipidemia as primary comorbidities are 83 patients $(33,03 \%)$, and only 5 patients have hypertension as primary comorbidity $(1,98 \%)$.

Table 7. The Top Ten Most Prescribed Drugs to Ischemic Stroke Patients within 2018

\begin{tabular}{llcc}
\hline No. & Drugs Type & Frequency & Percentage (\%) \\
\hline 1. & Drugs Affectting the Blood & 464 & 13,81 \\
2. & Electrolyte and Electrolyte Solution & 442 & 13,15 \\
3. & Vitamin & 374 & 11,13 \\
4. & Stress-Ulcer Drugs & 362 & 10,77 \\
5. & Anti-Hyperlipidemia & 315 & 9,38 \\
6. & Anti-Hypertension & 298 & 8,87 \\
7. & Anti-Diabetic & 256 & 7,62 \\
8. & Analgesic - Antipyretic & 154 & 4,58 \\
9. & Drugs that affect the respiratory & 143 & 4,26 \\
10 & Antibiotic & 122 & 3,63 \\
\hline & Total & 3360 & 100,00 \\
\hline
\end{tabular}

As shown in Table 7, the most prescribed patients with blood-affected drugs are 464 times (13,81\%), and 122 times are prescribed antibiotic $(3,63 \%)$.s 
1. Various Problems Related to Drugs

Table 8. Medication Error Occurred to Ischemic Stroke Patients within 2018

\begin{tabular}{clcc}
\hline No. & \multicolumn{1}{c}{ Type of Drug-Related Problems } & Number of Prescription & Percentage (\%) \\
\hline 1 & Wrong Patients & 2 & 6,67 \\
2 & Wrong Drugs & 2 & 6,67 \\
3 & Wrong Drugs Dosage & 1 & 3,33 \\
4 & Wrong Form of Drugs & 1 & 3,33 \\
5 & Wrong Directions of Drug Use & 1 & 3,33 \\
6 & Prescription Duplicate & 2 & 6,67 \\
7 & Receiving Drug Unsuccessfully & - & - \\
8 & Too-small Dosage & 8 & 26,67 \\
& - Acetylcysteine capsule & 6 & \\
& - Betahistine & 2 & \\
9 & Too-much Dosage & 13 & \\
& - Acetylcysteine capsule & 6 & \\
& - Atorvastatin tablet & 1 & \\
& - Clopidrogel tablet & 2 & - \\
& - Betahistine tablet & 4 & 100,00 \\
\hline & Unwanted Drug Reaction & - & \\
\hline
\end{tabular}

As shown in Table 8, the most medication error that occurred to ischemic stroke patients is too-much dosage with 13 prescriptions $(43,33 \%)$, while the least is wrong drugs dosage, wrong form of drugs, and wrong directions of drug use with one patient, respectively $(3,33 \%)$.

Table 9. The Number of Anti-Hypertension, Anti-Hiperlipidemia, and Anti-Diabetes Drugs Interaction on Ischemic Stroke Patients within 2018

\begin{tabular}{llccc}
\hline \multirow{2}{*}{ No } & Type of Drug & \multicolumn{3}{c}{ Drug Interaction Classification } \\
\cline { 3 - 5 } & & Major & Moderate & Minor \\
\hline 1 & Anti-Hypertension & 65 & 357 & 13 \\
2 & Anti-Hyperlipidemia & 41 & 315 & 2 \\
3 & Anti-Diabetes & 11 & 641 & 3 \\
\hline & & 117 & 1313 & 18 \\
\hline
\end{tabular}

As shown in Table 9. Most patients have a moderate level of drugs interaction with 1313 cases among the three types of drugs.

\section{DISCUSSION}

To conclude, the number of male patients is higher than the female, with 174 patients $(69,32 \%)$ and 77 patients (30,68\%), respectively. This result is in line with the study from Khan FY et.al. at a hospital in Qatar, in which their ischemic stroke patients consist of 33 males $(55 \%)$ and 27 females $(45 \%) .{ }^{8}$ Besides, Susanto et.al also stated in their study that 50 males $(65,79 \%)$ and 26 females $(34,21 \%)$ are ischemic stroke patients at Bethasda Hospital in Yogyakarta. ${ }^{9}$

Different physiology condition between males and females which caused by hormones which affect biological characters of both of them, such as fertility. Although male is stronger than female physically, from birth, female has stronger durability than male, either from pain or disease. Based on common case studies, males are at risk of a stroke three times greater than females. Male tends to get a non-hemorrhagic (ischemic) stroke, while female tends to get a hemorrhagic stroke. ${ }^{10}$

Stroke often occurs to males, because one of the conditions that causes stroke in male is Hypogonadism or lack of Testosterone hormone syndrome. Hypogonadism in males is a clinical syndrome caused by testis failures on producing Testosterone well. Based on the data, the number of patients with Hypogonadism in which over 80 years old is $94 \%$, while less than 10\% is 30-39 years old. Hypogonadism can cause metabolic disruption, for example: increasing total fat level, decreasing HDL cholesterol levels, and increasing LDL cholesterol level. Increasing LDL cholesterol level and decreasing HDL cholesterol level can generate disruptive risk on blood vessels, such as stroke or coronary heart disease. ${ }^{11}$

On the other hand, males tend to have unhealthy lifestyle, such as smoking. Devaranavadgi et.al. It shows that there is a strong correlation between smoking and increasing lipid plasma level: lipid plasma level depends on smoking duration and intensity. Lipid plasma abnormality could be increasing LDL level and decreasing HDL level, which could be related to coronary heart disease. A low level of HDL on smokers and exposure of cigarettes on the vessel's endothelium can cause atherosclerosis and coronary heart disease. ${ }^{12}$ Other studies conducted by Nastiti, et.al. conclude that stroke 
occurred more on males than females. ${ }^{13}$ Male tends to be exposed to ischemic stroke, while female tends to get subarachnoid bleeding which has death rate twice higher than happens on male. ${ }^{13,14}$

In this study, mostly stroke patients are at 50-60 years old (33,86\%). Age, gender, race, ethnic, and genetics are stroke's risk factors which can't be modified. Generally, stroke is a degenerative disease in which its incidence number is getting higher along with the increase of patients' age, with the twice number of cases in every decade after 55 years old (50-59 years old). ${ }^{15}$ The aging process causes deterioration of organs function, includes alternation in blood vessels on the brain. Blood vessels lost their elasticity, especially the endothelium layer which experiences thickening in the intima, and blood vessel lumen is tightened up, so that bloodstream to the brain is getting disruption. ${ }^{14}$ The high number of elderly stroke patients caused by the increasing amount of plague in blood vessels (atherosclerosis) at the age of more than 55 years old, and anytime the plague can fall apart which can cause emboli, later clogs up blood vessel to the brain and ends up with an ischemic stroke. ${ }^{15}$

Ischemic stroke patients here at PON Hospital mostly use JKN insurance to pay their treatment, with $87,64 \%$ (220 patients). This result indicated that JKN program was really useful for stroke patients, because stroke is featured in catastrophic disease (the disease which needs advance proficiency and medical devices, along with the long duration of therapy (lifetime)) which need long and costly medical treatment. ${ }^{16}$

A lot of comorbidities that happen to ischemic stroke patients make their length of stay longer than expected. Some studies, which are conducted in Japan (Manabe, et.al) and Manado (Amiman, et.al), about the correlation between Hypertension and length of stay shows that stroke patients with Hypertension need longer inpatients that the ones without. ${ }^{17,18}$ Stroke patients rate of clinical improvement shows the rate of clinical improvement is slowing down in older age patients. This condition also applies in patients who have comorbidities such as heart disease, diabetes mellitus, hypercholesterol.

Generally, stroke patients will be vulnerable to medical complication during medication which will affect patients' condition. Type of complication which generally occur are Pneumonia, urinary tract infection, constipation, pressure ulcer, etc, which caused by symptoms due to the stroke itself and the medication. Pneumonia, which caused by decreasing immunology status, and urinary tract infection are the common comorbidities that occur to the patients. ${ }^{19}$ Common symptoms which patients mostly experience such as immobilization, dysphagia, and cough reflex, also increase pneumonia risk in stroke patients. Urine catheter usage in stroke patients which could be pathogen entry point is being suspected as urinary tract infection trigger. Based on the study, this usage can increase urinary tract infection risk approximately $3-10 \%$ per day of catheter usage. The medical complication in stroke patients during treatment care will affect their rate of clinical condition improvement, which will extend their inpatient duration. ${ }^{19}$

Comorbid in ischemic stroke patients are diabetes, dyslipidemia, and hypertension. Diabetes can trigger stroke by some mechanism, such as endothelium vascular dysfunction, decreasing arterial stiffness, systemic inflammation, and increasing capillary basal membrane stiffness. In type II diabetes mellitus, there will be dysfunction in filling left ventricle diastolic which trigger congestive heart failure, microvascular disease, metabolism disruption, fibrosis interstitial, hypertension, and autonomous dysfunction. Blood vessel endothelium has an important function as structure and blood vessel wall integrity keeper, and vasomotor control. ${ }^{20}$ Nitric Oxide (NO) acts as vasodilator, and can cause endothelium dysfunction and trigger atherosclerosis cascade if their presence is low. The number of NO or blood vessel' smooth muscle reactivity to NO, will make the blood vessel become stiff and decrease its elasticity, compared with people with no diabetes. Type I diabetes mellitus is often associated with early structural disruption in carotid artery, which will make it thicker, as the early stage of atherosclerosis. Increasing inflammation response plays an important role in atherosclerotic plague development diabetes mellitus patients. ${ }^{20}$

In DM patients also seen an increase in the inflammatory response, inflammation plays an important role in the development of atherosclerotic plaque. C-reactive protein, cytokines, and adiponectin are the main markers of serum inflammation. C-reactive protein and plasma cytokine levels including interleukin-1, interleukin- 6 and tumor necrosis factor- $\alpha$ (TNF- $\alpha$ ) are independent predictors of cardiovascular risk. Adiponectin appears to be a modulator of lipid metabolism and systemic inflammation. Low adiponectin is also associated with CVD. ${ }^{20}$

High cholesterol levels, known as hyperlipidemia or dyslipidemia, contribute to blood vessel disease, which often causes strokes. There are two types of cholesterol: Low-density lipoprotein (LDL-C) is the cholesterol that builds up in the artery walls and High-density lipoprotein (HDL-C) called good cholesterol because it removes cholesterol from the bloodstream. The more HDL-C, the lower the risk of stroke, conversely the more LDL the greater the risk of stroke. When high cholesterol levels in the blood, LDL-C will accumulate in artery walls and narrow the arteries, a condition known as atherosclerosis that can block blood flow or cause blood clots, and can cause ischemic strokes. ${ }^{21}$

Hypertension can gradually increase blood pressure flowing through the arteries, the arteries will be damaged and narrowed. When there is fat from the diet entering the bloodstream, fat will accumulate in the damaged artery walls, so that the arterial walls become inelastic, which will restrict blood flow throughout the body. Uncontrolled high blood pressure can cause strokes by damaging and weakening brain blood vessels, causing them to narrow, rupture or leak. High blood pressure can also cause blood clots to form in arteries leading to the brain, blocking blood flow and potentially causing strokes. ${ }^{22}$ The number of accompanying diseases in ischemic stroke patients is not to mention the presence of medical complications such as pneumonia and urinary tract infections, so the drugs needed also become more. 
Based on the data obtained by the group of drugs that most widely used is drug that affects blood, namely, antiplatelet with active substances acetylsalicylic acid and clopidrogel. Anti-platelets (blood thinners) can prevent platelet adhesion from the walls of injured blood vessels or other platelets, which are the first steps in forming thrombus. ${ }^{23}$ The presence of thrombus in the lumen of blood vessels is one of the causes of ischemic stroke. In this study, data obtained with acetylsalicylic acid is often combined with clopidrogel. This is consistent with the results of the study that the combination of acetylsalicylic acid and clopidrogel for the treatment of acute transient ischemic attack (TIA) patients or ischemic stroke, is convincingly a reduction in recurrent ischemic stroke (compared to acetylsalicylic acid monotherapy), which lasts for 21 to 90 days. ${ }^{24}$

The second group of drugs which widely used is electrolytes and electrolyte fluids, and drugs which widely used are $0.9 \%$ sodium chloride solution. This $0.9 \% \mathrm{NaCL}$ infusion solution contains sodium and chloride. Intravenous fluids are most widely used in hospitalized patients to replace lost body fluids, correct electrolyte imbalances, and keep the body well hydrated. ${ }^{25}$ In addition, $9 \% \mathrm{NaCl}$ solution of small volume packs is used to dilute / dissolve injection drugs.

The third class of drugs which most widely used is vitamin groups consisting of vitamins B12, B6 and folic acid. Vitamin B12, Vitamin B6 and folic acid are most widely used in ischemic stroke patients, because they can reduce high homocysteine levels in plasma. Homocysteine is a natural amino acid, which, if high levels in the blood, can increase the risk of clogged arteries (aterosclerosis). Hyperhomocysteinemia can be caused by a deficiency of vitamin B12, vitamin B6, folic acid, or a combination of all three. Increased levels of homocysteine (more than 10 micromoles liters) in the blood can be associated with atherosclerosis, as well as an increased risk of heart attack, stroke, the formation of blood clots, and possibly Alzheimer's disease. ${ }^{26}$ From the results of the study of Saposnik et al. Giving a combination of $2.5 \mathrm{mg}$ of folic acid , $50 \mathrm{mg}$ of vitamin B6, and $1 \mathrm{mg}$ of vitamin B12 daily for 5 years is useful in preventing stroke and reducing cardiovascular events in stroke patients. ${ }^{27}$ The results of retrospective studies show that vitamin B therapy is a safe and economical way to prevent strokes and cardiovascular disease. ${ }^{28}$

The fourth group of drugs that mostly used is stress ulcer drugs, with the most active substances are ranitidine and omeprazole. The use of gastric acid-lowering drugs such as histamine $\mathrm{H} 2$ receptor antagonists and proton pump inhibitors (PPI) is often used to prevent stress ulcers, especially in critical patients such as ischemic stroke patients. ${ }^{29}$ Under normal circumstances, the stomach produces gastric acid which plays a role as the body's defense line from pathogens that enter through the digestive tract. With a gastric $\mathrm{pH}$ of around 2, most pathogens can be eliminated. The alkaline lining of the gastric mucosa functions to protect the stomach from stomach acid. Epithelial cells under this layer secrete mucus, bicarbonate, prostaglandins, and other protective factors. ${ }^{29,30,31}$

When conditions are stressed or critically ill, inflammatory processes, hypoperfusion, and microcirculation disorders will occur, which can cause a decrease in protective mechanisms. Hypoperfusion causes a decrease in the amount of prostaglandins and bicarbonate which will reduce mucus production. These conditions will interfere with mucosal integrity and increase stomach acid production which will cause stress ulcers. Most ischemic stroke patients receive treatment with ranitidine and omeprazole to prevent the occurrence of stress ulcers, besides the use of this drug also to prevent bleeding due to the use of antiplatelet agents such as low-dose aspirin and clopidrogel. ${ }^{31}$

The fifth most common group of drugs is antihyperlipidemia with active substances simvastatin and atorvastatin. Statins are widely used in the treatment of embolic strokes, which is caused by fat clots (embolus) moving from other places in the body through blood flow, if the embolus clogs arteries heading to the brain, it can cause strokes. ${ }^{32}$ Statin is effective in lowering cholesterol, which can prevent coronary events both in people who have not suffered coronary heart disease/CHD (primary prevention) and for those who have CHD (secondary prevention). In addition to lowering cholesterol, statins can improve endothelial function, increase HDL cholesterol and inhibit matrix metalloproteinases (substances that make flak unstable). ${ }^{33}$

The hypertension drug group is the sixth most common drug, with the most active ingredient used bisoprolol and amlodipine. Bisoprolol is the most selective beta- blocker among all beta-blockers among all selective beta-blockers. Bisoprolol can reduce the consumption of $\mathrm{O}_{2}$ (oxygen) in the myocardial so that bisoprolol is very useful for tachyarrhythmic patients or in patients with coronary heart disease (CHD). Bisoprolol can reduce the rate of the heart (negative chronotropic) and myocardial contractility (negative inotropic) which causes decreased cardiac output (cardiac output), besides this drug also inhibits renin secretion from the kidneys and decreases peripheral resistance. Thus bisoprolol can reduce blood pressure. Bisoprolol also has the effect of improving ventricular function through a mechanism which is not yet known exactly, therefore, bisoprolol is included in the list of heart failure drugs. Bisoprolol is a selective beta blocke that is very effective in reducing blood pressure due to the overstimulation of the sympathetic nerves, so it is the first choice drug in hypertensive patients with CHD (angina pectoris or after myocardial infarction). ${ }^{33}$

Treatment with bisoprolol should start with a low dose with a gradual increase (1-2 week intervals) for the target dose. Treatment generally starts with a dose of $1.25 \mathrm{mg}$ once a day every day with subsequent increases to $2.5 \mathrm{mg}, 3.75$ $\mathrm{mg}, 5 \mathrm{mg}, 7.5 \mathrm{mg}$, and $10 \mathrm{mg} /$ day, if tolerated. In normal subjects, the half-life is long (10-11 hours) and even longer in patients with heart failure (17 \pm 5 hours) and / or with severe kidney failure making it possible to administer bisoprolol once a day. Bisoprolol does not interfere with the metabolism of other drugs. In the first CIBIS trial, the target dose of bisoprolol was $5 \mathrm{mg}$ bisoprolol and it did not significantly reduce mortality, but in CIBIS-II, a dose of bisoprolol $10 \mathrm{mg}$ could reduce mortality. ${ }^{34}$ 
Amlodipine is a unique calcium channel blocker, besides it is long acting, amlodipine has antioxidant properties and it can increase the production of NO (nitric oxide) so that it can improve endothelial function. Amlodipine can inhibit the progression of atherosclerosis, reduce cardiovascular events and mortality in CHD patients. As antihypertensive drug, amlodipine can reduce blood pressure slowly, so it does not cause tachycardia. Amlodipine is available in two packages of $5 \mathrm{mg}$ and $10 \mathrm{mg}$ given orally once a day. ${ }^{33}$

Antidiabetic drugs are the seventh most common class of drugs with the most active substances used are Metformin and Glulisine / Apidra Solostar. Metformin has no stimulatory effect on pancreatic beta cells, so it does not cause hypoglycemia and weight gain. Giving metformin can reduce mild to moderate weight, due to appetite suppressants and decreases hyperinsulinemia due to insulin resistance. Therefore, it is not considered a hypoglycemic drug but an antihyperglycemic drug. ${ }^{35}$

Metformin can also be used as monotherapy and as a combination therapy with sulfonylureas (SU), such as gliquidone, glimepiride. In a single use metformin can reduce blood glucose up to $20 \%$ and plasma insulin concentration in the basal state also decreases. Given the superiority of metformin in reducing insulin resistance, preventing weight gain and improving lipid profile, metformin as the first choice monotherapy in early diabetes management in obese people with dyslipidemia and severe insulin resistance. The combination of sulfonylureas with metformin is now rational combination because it has a synergistic way of working so that this combination can reduce blood glucose more than each single treatment. The combination of metformin and insulin can also be considered in obese patients with glycemia that is difficult to control. ${ }^{35}$

The use of insulin for DM patients is widely used in inpatients because the average patient is in an unstable condition of blood glucose levels so that prompt treatment is needed to provide a therapeutic effect, in this case giving insulin is appropriate, because insulin is a hormone that plays an important role in metabolism, which helps transport glucose into cells. ${ }^{36}$

The most widely used type of insulin preparation is Insulin Glulisine/Apidra Solostar. Insulin glulisine is a a fastacting type of insulin or known as rapid-acting insulin, meaning that this insulin starts working 15 minutes after injection, the peak levels in the blood for about 1 hour, and continues to work for 2 to 4 hours. Glulisine insulin reaches its peak life period after 30-90 minutes and will last for 3-5 hours. ${ }^{37}$

Glulisine insulin seems to have the fastest action of insulin analogs, can provide better glycemic control and reduce the risk of hypoglycemia compared to ordinary insulin. This insulin is very useful in patients with a high risk of hypoglycemia or insulin allergy. ${ }^{37}$

Insulin is needed when: 1) HbA1c value> 9\%; 2) Metabolic decompensation conditions; 3) rapid weight loss; 4) Severe hyperglycemia accompanied by ketosis; 5) Hyperglycemia crisis; 6) Failure with the combination of oral antidiabetic (ADO); 7) Severe stress (systemic infection, major surgery, acute myocardial infarction, stroke); 8) Severe impairment of kidney or liver function; 9) contraindications or allergies to ADO; 10) Preoperative conditions (before surgery); 11) Operative conditions are according to the indications. ${ }^{38}$

The eighth highest class of drugs used by ischemic stroke patients is analgesic-antipyretic with active substance Paracetamol. Fever in stroke patients can be caused by the stroke itself, possibly due to massive tissue necrosis, which can increase body temperature, or the presence of blood in the brain. ${ }^{39}$ From two separate meta-analyzes showing that high body temperature after stroke, is associated with morbidity and mortality which is significantly higher compared to normothermic patients. According to the European Stroke Organization, if fever occurs, body temperature should be monitored at the same time as the search for possible infection begins when the body temperature is above $37^{\circ} \mathrm{C}$. The American Heart Association - American Stroke Association guidelines recommend that in periods of acute stroke, a high body temperature should be lowered. both in ischemic and hemorrhagic strokes with antipyretic agents. ${ }^{40}$

Paracetamol is the most widely used drug based on the results of a Meta-analysis conducted by Chen et al., found that paracetamol significantly reduces body temperature 24 hours after a stroke and reduces mortality at 7 or 14 days in patients with ischemic and hemorrhagic strokes. Paracetamol is considered as the ideal solution to avoid hyperthermia because it is easy to use, works quickly, and is widely available. This study also showed that paracetamol did not cause an increase in serious side effects, including liver failure and infection. ${ }^{41}$

Respiratory drugs are the ninth most common group of drugs with active ingredients $\mathrm{N}$-acetylcysteine and salbutamol. The problem that often arises in stroke patients is impaired movement (immobilization) or disruption in muscle strength that will have an impact on daily activities. As a result of immobilization will occur sputum and aspirarial retention, especially in geriatric patients. In the lying position the diaphragm and intercostal muscles do not function properly, so that chest movement also becomes limited which makes sputum (mucin) difficult to get out. ${ }^{42}$

To facilitate the removal of sputum,] N-acetylcystein (NAC) is used as mucolytic. N-acetylcysteine works by breaking the bonds between mucin protein molecules (the main component of mucus) into smaller fragments, making the mucus more fluid and easier to remove. But mucin in the lung mucus is not the only protein in the human body to form such molecular bonds. The same types of protein molecular bonds can also be found in blood vessels, by involving the Von Willebrand factor, proteins can cause platelet buildup and form blood clots. Thus the administration of $\mathrm{N}$ acetylcysteine, to stroke patients in addition to being mucolytic it also functions as an antithrombosis (breaking down blood clots) which can eliminate thrombus in the bloodstream. ${ }^{43}$ 
For stroke patients who also have asthma, doctors will prescribe salbutamol as a bronchodilator, in the form of inhalation, in addition to $\mathrm{N}$-acetylcystein. Salbutamol is an $\beta 2$ adrenergic receptor agonist, works in the $\beta 2$ receptor in the bronchi, salbutamol binding in the receptor will activate the enzyme adenylcyclase, which will convert ATP to cAMP (cyclic-adenosine-monophosphate). The level of cAMP in cells will increase will produce bronchodilatory effects. ${ }^{44}$ Thus, mucin in the airways is made liquid and easily released by $\mathrm{N}$-acetylcystein, while salbutamol causes the airway muscles to relax so that the air flow in the airway becomes smooth.

Antibiotics are the seventh most widely used drug in ischemic stroke patients, to treat 1) urinary tract infections (UTIs) caused by germs including Escherichia coli, Proteus morganella, Pseudomans aeruginosa, Stasphylococcus epidermis, Enterococci, and Staphylococcus aureus, due to use the of folley catheters, post stroke disability, old age, low immunity status, diabetes mellitus, and other types of antibiotics which include cefixime, ofloxacin, ciprofloxacin, cotrimoxazol; ${ }^{45}$ 2) Nosocomial pneumonia, ventilator-associated pneumonia (VAP) and health center-related pneumonia can be caused by various types of pathogenic bacteria such as Pseudomonas aeruginosa, Escherichia coli, Klebsiella pneumoniae, Acinebacter sp, and Staphylococcus aureus which often found in DM patients. Further, based on the indications, patients with ischemic stroke accompanied by other diseases such as DM, is given fluoroquinolone antibiotics (moxifloxacin, gemifloxacin, levofloxacin), betalactam with macrolide, cefuroxim ceftriaxone, and cefpodoxime. $^{46}$

The medication errors encountered in this study were the wrong patient, medication, medication dose, medication regulation, medication dosage form, and prescription duplication. Electronic prescription model can occur as a doctor forgets to change the medical record number, for different patients; patients get duplicate prescriptions, for example stroke patients who are under the responsibility of neurosurgeons and internal medicine specialists, sometimes doctors prescribe the same drugs (drug duplication). Prescription drugs with too low or to high doses can occur because a doctor has mistyped a prescription, for example drugs must be taken 3 times daily 1 capsule, but those drugs are prescribed $1 \mathrm{x}$ daily 1 capsule. ${ }^{47}$ However, in order to prevent further occurrence of the medication errors above, the development of medication error reporting and management system at hospital are urgently needed, for example, clinical pharmacists who play a vital role in identification and prevention of medication errors, should work together with the health care team for the betterment of quality of life of the patients. ${ }^{48}$

Antihypertensive drugs, antilipidemics and antidiabetic three drugs are widely used, because hypertension, lipidemics and diabetes are the most common accompanying diseases in ischemic stroke patients. More than one drug used for each type of concomitant disease. The principle of testing hypertension by following the hypertension treatment algorithm according to the Guidelines of the European Society of Hypertension (ESH) and of the European Society of Cardiology (ESC) 2007 is when hypertension is high or very high cardiovascular (CV) risk, it is recommended to use two or more drugs. Based on Laragh's concept, if the hypertension patient is young, the drug is Angiotensin-converting-enzyme inhibitors (ACE inhibitors) and Angiotensin II Receptor Blockers (ARB) and beta blockers (BB), whereas in hypertensive elderly patients (erderly hypertension) the drugs are Calcium channel blockers (ARB) and beta blockers (BB), whereas in hypertensive elderly patients (erderly hypertension) the drugs are Calcium channel blockers (ARB) and beta blockers (BB). CCB) and diuretics. ${ }^{47}$

Likewise, hyperlipidemia in patients with atherogenic dyslipidemia (AD) is a condition that refers to increased levels of triglycerides (TG), Low density lipoprotein (LDL) and low levels of High density lipoprotein (HDL). If the patient has high cholesterol, LDL and triglyceride levels, then the drugs needed are not only drugs that can inhibit the enzyme HMG-CoA reductase (derivate statin), drugs that inhibit cholesterol formation are also given other drugs that can reduce blood triglyceride levels such as gembifrozil and phenofibrate. ${ }^{48}$ Antidiabetic can be used more than one drug in certain circumstances if the target blood glucose level has not been achieved with a combination of two kinds of drugs, can be given a combination of two antihyperglycemia drugs with insulin. ${ }^{49,50}$

The medication errors encountered in this study were the wrong patient, medication, medication dose, medication regulation, medication dosage form, and prescription duplication. Electronic prescription model can occur as a doctor forgets to change the medical record number, for different patients; patients get duplicate prescriptions, for example stroke patients who are under the responsibility of neurosurgeons and internal medicine specialists, sometimes doctors prescribe the same drugs (drug duplication). Prescription drugs with too low or to high doses can occur because a doctor has mistyped a prescription, for example drugs must be taken 3 times daily 1 capsule, but those drugs are prescribed $1 \mathrm{x}$ daily 1 capsule. ${ }^{51}$ However, in order to prevent further occurrence of the medication errors above, the development of medication error reporting and management system at hospital are urgently needed, for example, clinical pharmacists who play a vital role in identification and prevention of medication errors, should work together with the health care team for the betterment of quality of life of the patients. ${ }^{52}$

In patients who are accompanied by clinical reasons where insulin is not possible to use, therapy can be given a combination of three oral antihyperglycemia drugs. The presence of comorbidities such as hypertension, lipidemia and diabetes, plus the side effects of drugs, so that these patients need more drug therapy. The number of drug used will cause a lot of drug interactions. Drug interactions occur if the effect of a drug (index drug) changes due to the presence of other drugs (precipitant drugs), food, or drinks. Drug interactions can produce undesirable effects (Undesirable / Adverse Drug Interactions = ADIs) which commonly cause drug side effects and / or toxicity due to increasing levels of drugs in plasma, or conversely decreasing levels drugs in plasma that cause the therapeutic results to be suboptimal. 
Antihypertensive interactions with other drugs can be in the form of hypotension, antidiabetic interactions with the other drugs which can cause hypoglycemic effects and the interactions of other drugs with hyperlipidemic drugs (statins) which can increase statin levels in the blood that can cause rhabdomyolysis. The occurrence of effects due to drug interactions to avoid the drugs to be given to patients should always be seen / observed whether there are interactions, therefore, the occurrence of undesired drug effects can be avoided..$^{53,54}$

\subsection{Conclusion}

\section{CONCLUSION AND SUGGESTIONS}

According to the results, the conclusions are interpreted as follows :

1. The number of male ischemic stroke patients is 174 people $(69.32 \%)$ and the number of female patients is 77 people $(30.68 \%)$.

2. The highest number of ischemic stroke patients in the age range of 50-60 years, is 85 people (33.86\%) and the least is at the age of less than 40 years as many as 7 people $(2.79 \%)$.

3. Most types of ischemic stroke patient financing are 220 patients who join National Health Insurance (JKN) funding programs $(87.64 \%)$ and only 1 patient who joins the company insurance $(0.40 \%)$.

4. The longest stay of ischemic stroke patients in the hospital is more than 60 days, 1 person $(0.40 \%)$ and the shortest is between 3-10 days, as many as 225 people $(89.64 \%)$.

5. The highest number of drug items received by one patient is between $70-80$ drug items $(0.40 \%)$ and the least is between 5-10 drug items received by 60 patients

6. The most accompanying diseases in ischemic stroke patients are hypertension + hyperlipidemia as many as 83 people $(33.03 \%)$ and the least is hypertension as many as 5 people $(1.98 \%)$.

7. The most commonly used class of drugs in ischemic stroke patients is the drug group that affects blood with a frequency of 468 times (13.81\%) and the least is the antibiotic group with a frequency of 122 times $(3.63 \%)$.

8. Medication Errors that occur the most are giving drugs with a dose as much as 13 times (43.33\%), and at least one dose of drug, wrong form of drug preparation and wrong drug rules of $3.3 \%$ each

9. Most drug interactions are drug interactions with moderate criteria as many as 1313 interactions, and the drug groups which have the most interactions are antidiabetic drugs as many as 641 interactions.

\subsection{Suggestion}

The following suggestions are given based on the results of the study :

1. For PON Hospital, it is considered that many types of drugs used in the treatment of ischemic stroke patients such as drugs to treat the disease (antihypertensive, antidiabetic and hyperlipidemic drugs), should always be checked in terms of drug interactions. Therefore, the effects of drug effects that are not desirable can be avoided.

2. For the future researchers:

It is a good opportunity to investigate more on drug related problems in hemorrhagic stroke patients at the National Brain Center hospital.

\section{ACKNOWLEDGEMENT}

The author would like to thank Joko Sulistyo, ST, MSi, Director of the Health Polytechnic of the Ministry of Health, Jakarta II, who has provided financial support from DIPA Poltekkes Kemenkes Jakarta II Tahun 2019. We also thank the Director of PON Jakarta Hospital Dr., Mursyid Bustami, Sp.S, KIC for allowing us to collect data at PON Hospital. A special thanks goes to the Editor, who read each chapter quickly after it was submitted to him and provided both valuable edits and suggestions for improvements marked in each chapter.

\section{REFERENCES}

1. The Atlas of Heart Disease and Stroke. Available from: https://www.who.int/cardiovascular_diseases/resources/atlas/en/, [Accessed 17th January 2019].

2. Setiap Tahun Terdapat 550.000 Pasien Baru Stroke di Indonesia. Data tersedia pada situs internet: https://kebijakankesehatanindonesia.net/25-berita/berita/1428-setiap-tahun-terdapat-550000-pasien-baru-stroke-diindonesia. [Accessed 17th January 2019].

3. Indonesia Stroke Society Luncurkan Kampanye Melawan Stroke, Data tersedia pada situs internet: www.tribunnews.com > Kesehatan > Health \& Concerns. [Accessed 17th January 2019].

4. Condition That increase Risk for Stroke. Available from: https://www.cdc.gov/stroke/conditions.htm. [Accessed 17th January 2019]. 
5. Kanagala VS, Annapareddy A, Rao BS, Challa SR, Nalla KS, Gadde RS. A study of medication-related problems in stroke patients: A need for pharmaceutical care. J Res Pharm Pract. 2016 Jul-Sep; 5(3): 222-25.

6. Viktil KK, Blix HS. The impact of clinical pharmacits on drugrelated problems and clinical outcomes. Clin. Pharmacol. Toxicol. 2008 Mar;102(3):275-80.

7. Ganachari MS, Mahendra Kumar BJ, Shashikala C Wali, Fibin M. Assessment of drug therapy interventions by clinical pharmacist in a tertiary care hospital. ijopp 2010;3(3): 22-8. 6.

8. Khan FY, Ibrahim AS. Gender differences in risk factors, clinical presentation, and outcome of stroke: A secondary analysis of previous hospital-based study in Qatar. LJMS 2018; Volume 2 Issue 2: 51-5.

9. Susanto FE, Pinzon RT, Widyo K. Pengaruh infeksi saluran kemih sebagai faktor prognosis stroke iskemik akut di Rumah Sakit Bethesda Yogyakarta. JKK 2017; Volume 4, No 2: 49-55.

10. Nabyl RA. Deteksi dini gejala dan pengobatan stroke. Yogyakarta : Aulia Publishing; 2012.

11. Bushnell CD, Johnston DC, Goldstein LB. Restrospective Assessment of Initial Stroke Severity: Comparison of the NIH Stroke Scale and The CNS. Jurnal Stroke 2009; Volume 32: 656.

12. Devaranavadgi BB, Aski BS, Kashinath RT, Hundekari IA. Effect of Cigarette Smoking on Blood Lipids - A Study in Belgaum, Northern Karnataka, India. Global Journal of Medical Research. 2012; Volume 12 Issue 6:57-61

13. Nastiti. Gambaran Faktor risiko kejadian stroke pada pasien stroke rawat inap di rumah sakit Krakatau Medika Tahun 2011. Jakarta: Universitas Indonesia; 2012.

14. Junaidi I. Stroke waspadai ancamannya. Yogyakarta: PT Bhuana Ilmu Populer Kelompok Gramedia; 2011.

15. Boehme AK, Esenwa C, Elkin MSV. Stroke Risk Factors, Genetics, and Prevention. Circ Res.2017 Feb 3: 120(3) 472-95.

16. Bantah Isu yang Beredar, BPJS Kesehatan Pastikan Tetap Jamin Biaya 8 Penyakit. High cholesterol — Stroke Foundation - Australia. Available from: https://ekonomi.kompas.com/read/2017/11/27/082633626/bantah-isuyang-beredar-bpjs-kesehatan-pastikan-tetap-jamin-biaya-8-penyakit?page=all. [Accessed 7th November 2019].

17. Manabe Y, Kono S, Tanaka T, Narai H, Omori N. High blood pressure in acute ischemic stroke and clinical outcome. Neurol Int.2009; 1(1): e1.

18. Amiman RC, Tumboimbela MJ, Kembuan MAHN. Gambaran length of stay pada pasien stroke rawat inap di RSUP Prof. Dr. R. D. Kandou Manado periode Juli 2015-Juni 2016. Jurnal e-Clinic (eCl); Volume 4, Nomor 2 : Juli-Desember 2016

19. Ingeman A, Andersen G, Hundbora HH, Svendsen ML, Johnsen SP. In-hospital medical complications, length of stay, and mortality among stroke unit patients. stroke. 2011 ; 42:3214-8.

20. Chen R, Ovbiagele B, Feng Wuwei. Diabetes and stroke: Epidemiology, pathophysiology, pharmaceuticals and outcomes. Am J Med Sci. 2016 Apr; 351(4): 380-86.

21. High cholesterol - Stroke Foundation - Australia. Available from: https://strokefoundation.org.au > About-Stroke > Prevent-Stroke [Accessed 27th October 2019].

22. High blood pressure dangers: Hypertension's effects on your body. Available from: https://www.mayoclinic.org/diseases-conditions/high-blood-pressure/in-depth/high-blood-pressure/art-20045868. [Accessed 23th October 2019].

23. Setiabudy RD. Hemostasis dan thrombosis. Dalam: Farmakologi dan terapi Edisi ke enam. Jakarta: FKUI; 2016

24. Hackam DG, Spence JD. Antiplatelet therapy in ischemic stroke and transient ischemic attack. an overview of major trials and meta-analyses. Stroke. 2019;50 No.3 :773-78

25. Jenis cairan infus dan kegunaannya Available from: https://www.alodokter.com/dasar-dasar-prosedurmemanfaatkan-cairan-infus. [Accessed 5th November 2019].

26. Saposnik G, Ray JG, Sheridan P, McQueen M, Lonn E. Homocysteine-lowering therapy and stroke risk, severity, and disability additional findings. Stroke AHA J. 2009: 40:1365-72.

27. Homosistein dan resiko penyakit pada pembuluh darah Available from: www.eisai.co.id > third node > fourth > disease11-id. Accessed 10th December 2019].

28. Herrmann W, Obeid R. Homocysteine-lowering treatment in reduction of stroke and coronary vascular risk - Do not give up. European Cardiology. 2008; 4 (2): 20-3.

29. Krag M, Perner A, Wetterdlev J, Wise MP, Borthwick M, Bendel S, et al. Prevalence and outcome of gastrointestinal bleeding and use of acid suppressants in acutely ill adult intensive care patients. Intensive Care Med. 2015;41:833-45

30. Cook D, Guyatt G. Prophylaxis against upper gastrointestinal bleeding in hospitalized patients. N Eng J Med. 2018;378(26):2506-2516

31. Buendgens L, Koch A, Tacke F. Prevention of stress-related ulcer bleeding at the intensive care unit: risks and benefit of stress ulcer prophylaxis. World J Crit Care Med. 2016;5(1):57-64

32. Types of strokes. Available from: https://www.texasheart.org/heart-health/heart-information- center/topics/typesof-strokes/, [Accessed 3th December 2019]. 
33. Kabo P. Bagaimana menggunakan obat-obat kardiovaskular secara rasional. Jakarta: Badan Penerbit FKUI 2010: 38-41.

34. Metra M, Nodari S, Bordonali T, Milani P, Lombardi C, Bugatti S, Fontanella B, et al. Bisoprolol in the treatment of chronic heart failure: from pathophysiology to clinical pharmacology and trial results. Therapeutics and Clinical Risk Management 2007:3(4); 569-78.

35. Soegondo S. Farmakoterapi pada pengendalian glikemia diabetes melitus tipe 2. Dalam: Setiati S, Alwi I, Sudoyo AW, Simadibrata M, Setiyohadi B, Syam AF. Editor. Ilmu Penyakit Dalam. Jilid II Edisi VI. Jakarta: Internal Publishing; 2014. 2328-35.

36. Pramita Z, Aditama L. Efektivitas edukasi terapi insulin terhadap pengetahuan dan perbaikan glikemik pasien diabetes melitus. Jurnal Farmasi Klinik Indonesia 2013; 2: 137.

37. Insulin glulisin, Available from: https://www.drugs.com/mtm/insulin-glulisine.html [Accessed 12th October 2019].

38. Soelistijo SA, Novida H, Rudijanto A, Soewondo P, Suastika K, Manaf A, Sanusi H, et al. Konsensus pengelolaan dan pencegahan diabetes melitus tipe 2 di Indonesia 2015. Jakarta: PB Perkeni; 1-87.

39. Wrotek SE, Wieslaw E. Kozak WE, Hess DC, Fagan SC. Treatment of fever after stroke: conflicting evidence. Pharmacotherapy. 2011; 31(11): 1085-1091.

40. Keeratikunakorn T, Watcharasaksilp K, Chaiwarith R. Incidence of Fever in Patients Diagnosed with Cerebrovascular Diseases in a Tertiary Care Hospital in Northern Thailand. J Neurol Neurosurg.2016; 3(2) 129:

41. Georgilis K, Plomaritoglou A, Dafni U, Bassiakos Y, Vemmos K. Aetiology of fever in patients with acute stroke. J Intern Med. J. Intern.1999;246(2):203-9.

42. Setiani S, GavindaA. Imobilisasi pada usia lanjut. Dalam: Setiani S, Alwi I, Sudoyo AW, Simadibrata M, Setyohadi B, Syam AF. Editor. Ilmu penyakit dalam. Jilid III Edisi VI. Jakarta: InternaPublishing; 2014. $3758-70$.

43. Lizarrondo SM, Gakuba C, Herbiq BA, Repesse Y,Ali C, Denis CV, Lenting PJ, et al. Potent Thrombolytic effect of N-Acetylcysteine on Arterial Thrombi.Circulation. 2017;136:646-60.

44. Gunawan SG, Setiabudy R, Nafrialdi, Asma bronkial, Dalam: Setiawati A, Gan S, Editor, Farmakologi dan terapi, Edisi 6, Jakarta: Badan Penerbit FKUI; 2016. 63-82.

45. Harris S, Al Rasyid. Urinary tract infection (UTI) Dalam: Al Rasyid, Misbach Y, Harris S. Stroke, Kompilasi medis dan tatalaksana. Jakarta: Badan Penerbit FKUI; 2015. 77-81.

46. Amin Z. Stroke dan pneumonia. Dalam: Al Rasyid, Misbach Y, Harris S. Stroke, Kompilasi medis dan tatalaksana. Jakarta: Badan Penerbit FKUI; 2015. 19-33.

47. Yogiantoro M. Pendekatan klinis hipertensi. Dalam: Setiani S, Alwi I, Sudoyo AW, Simadibrata M, Setyohadi B, Syam AF. Editor. Ilmu penyakit dalam. Jilid III. Edisi VI. Jakarta: InternaPublishing; 2014. 2259-83.

48. Adam JMF. Dislipidemia. Dalam: Setiani S, Alwi I, Sudoyo AW, Simadibrata M, Setyohadi B, Syam AF. Editor. Ilmu penyakit dalam. Jilid III. Edisi VI. Jakarta: InternaPublishing; 2014. 2549-58.

49. Soegondo S. Farmakoterapi pada pengendalian glikemia diabetes melitus tipe 2 Dalam: Setiani S, Alwi I, Sudoyo AW, Simadibrata M, Setyohadi B, Syam AF. Editor. Ilmu penyakit dalam. Jilid III. Edisi VI. Jakarta: InternaPublishing; 2315-35.

50 Soelistijo SA, Novida H, Rudijanto A, Soewondo P, Suastika K, Manaf A, Sanusi H, dkk. Konsensus pengelolaan dan pencegahan diabetes melitus tipe 2 di Indonesia 2015. Jakarta: Perkeni; 1-82.

51. Yen-Fu C, Neil KE, Avery AJ, Dewey ME, Johnson C. Prescribing errors and other problems reported by community pharmacists. Therapeutics and Clinical Risk Management 2005:1(4) 333-42

52. Abhimanyu P, Vijit A. Medication errors and role of clinical pharmacist in identification, assessment and prevention: Need of the time. Asian Journal of Pharmacy and Life Science.2016; 6 (4): 1-13.

53. Giwati R. Interaksi obat dan beberapa implikasinya. Media Litbang Kesehatan.2008; Vol XVIII (4): 175-84.

54. Drug.com. Available from: https://www.drugs.com/comments/drug interaction/ [Accessed 22th June 2019]. 